\title{
The Impact of Media and Cultural Beliefs on Women's Participation in Sports in Turkey: The Challenges faced by Turkish Women in Professional Sports
}

Meltem INCE-YENILLMEZ (https://orcid.org/0000-0002-4689-3196), Department of Economics, Yaşar University,Turkey; e-mail: meltem.ince@yasar.edu.tr

\section{Medya ve Kültürel İnançların Türkiye'de Kadınların Spora Katılımı Üzerindeki Etkisi: Profesyonel Sporda Türk Kadınlarının Karşılaştığı Zorluklar}

\begin{abstract}
The fight for gender equality in Turkey extends as far as the sports sector of the economy. Although Turkey has recently seen a fast rise in the participation of women in sports, female athletes are still being marginalized for many reasons. The alarming levels of discrimination discourage females from entering into professional sports in Turkey and have inhibited the growth of the female sports sector in Turkey. This research aims to examine the different roles women have to take with emphasis on explaining the relationship between sports and politics in modern Turkey. The present study explores Turkish women's specific constraints and challenges in professional Sports. Qualitative data were generated from semi-structured interviews conducted with 142 female athletes (both amateur and professionals) across different cities in Turkey. The findings of the study indicate that family influence $(\chi=4.39$ of 5$)$, wage inequality $(\chi=4.31$ of 5$)$, media misrepresentation $(\chi=4.16$ of 5$)$, inadequate sports facilities for women $(\chi=4.12$ of 5$)$ and high levels of sexual harassment $(\chi=3.89$ of 5) are the constraints that must be addressed to improve the climate for female participation in sports significantly. The study highlights how these physical activities and sports programs play essential roles in increasing awareness of their importance and improving the overall perception of women in sports in Turkey.
\end{abstract}

Keywords

Professional Sports, Female Athletes, Gender Discrimination.

JEL Classification Codes : J16, J71, L83.

\section{$\ddot{\mathbf{O z}}$}

Türkiye'de toplumsal cinsiyet eşitliği ile mücadele spor sektörüne kadar uzanmaktadır. Son zamanlarda kadınların spora katılımında hızlı bir artış görülmesine rağmen, kadın sporcular birçok nedenden ötürü marjinalleştirilmektedir. Karşılaştıkları ayrımcılıklar kadınların Türkiye'de profesyonel spora girmesini engellemekte ve Türkiye'de kadın spor sektörünün gelişmesine imkân vermemektedir. Bu araştırmanın amacı, modern Türkiye'de spor ve siyaset arasındaki ilişkiyi baz alarak kadınların üstlendiği farklı rolleri incelemektir. Bu çalışma, Türk kadınlarının profesyonel sporda karşılaştığı kısıtlamaları ve zorlukları araştırmaktadır. Türkiye'de farklı şehirlerdeki 142 kadın sporcu ile (amatör ve profesyonel) yapılan görüşmelerden nitel veriler elde edilmiştir. Ailenin etkisi $(\chi$ $=4.39 / 5)$, ücret eşitsizliği $(\chi=4.31 / 5)$, medyanın yanlış yönlendirmesi $(\chi=4.16 / 5)$, kadınlar için yetersiz spor tesisleri $(\chi=4.12 / 5)$ ve yüksek seviyede cinsel taciz $(\chi=3.89 / 5)$ kadınların spora katılımını artırmak için ele alınması gereken en önemli sorunlardır. Çalışma, fiziksel aktivite ile spor programlarının öneminin farkındalığını artırmak ve Türkiye'de spor yapan kadınların genel algısını geliştirmek için gereken önemli roller vurgulanmaktadır. 
İnce-Yenilmez, M. (2021), “The Impact of Media and Cultural Beliefs on Women's Participation in Sports in

Turkey: The Challenges faced by Turkish Women in Professional Sports", Sosyoekonomi, 29(48), 91-106.

Anahtar Sözcükler $\quad$ : $\quad$ Profesyonel Spor, Kadın Sporcular, Cinsiyet Ayrımcılığı.

\section{Introduction}

Sports have always been more than a social activity; it is considered one of the most valuable social tools for connecting individuals across the local and global landscape (Velazquez, 2017). On a personal scene, sports can equally play a psychological, social, emotional, mental, and physical developmental role in the lives of participants (Khan, 2012). However, the reality is quite different especially for women in sports. Many women have been exposed to numerous kinds of discrimination and social exclusion, for example, sexism, gender inequality, and homophobia (Cleland, 2014). Many sports scholars have investigated this "dark side" of sports revealing that sports have in the past reinforced damaging and dangerous social patters such as excessive violence, homophobia, gender inequality and racism (LaVoi \& Kane, 2011, 376).

There are countries in the world where women are not allowed to participate in professional sports, whereas some other countries allow participation but with severe levels of discrimination in diverse areas, including the kind of picture depicted by the media.

Diverse schools of thought have carried out studies about the reasons that promote female involvement in sports and physical activities in several groups, although there is a handful of literature that has actually discussed the problems that influence female participation in sporting activities (Weber \& Carini, 2012; Ahmad, 2015; Ballantyne, Kayser \& Grootegoed, 2012).

In times past, sports were considered a male-dominated world, and women were considered outsiders in the game. This means that the world of sports has always been perceived as more masculine than feminine. These views are also held by diverse countries in the world (Hardin \& Croston, 2012; Feldman et al., 2003; FIFA, 2015; Saavedra \& Martha, 2010). Initially, women were perceived to be the other sex; they were not the leading insiders and were mainly considered to be latecomers or newbies who were only given permission to participate in friendly games or sports (FIFA, 2015).

A belief was equally held that women were only suitable to partake in particular sporting activities with less strenuous efforts, while men were allowed to take part in a diverse range of sporting activities (Ruseki et al., 2011; FIFA, 2015). For instance, it has always been perceived that women are more suited to gymnastics and dancing while men were footballers (Fahmy, 2011; FIFA, 2015). This assumption was held from the early 19th century and was based not only on gender differences and convictions but also on scientific knowledge (Feldman et al., 2003). A Famous philosopher Buytendijk in 1953, talked on the subject of female football, referencing it, as "a game is essentially a demonstration of masculinity as we understand it from our traditional view of things and as produced in part by our physical constitution (through hormonal irritation). No one has ever been successful in getting women to play football" (Buytendijk, 1953: 20). 
İnce-Yenilmez, M. (2021), "The Impact of Media and Cultural Beliefs on Women's Participation in Sports in

Turkey: The Challenges faced by Turkish Women in Professional Sports", Sosyoekonomi, 29(48), 91-106.

Several studies have equally shown that more females than males are involved in low and moderate physical activity groups, and more males than females in the high activity group. Another study by FIFA concerning women's football in 2014 equally showed that the perception that women should be allowed to play sports activities like football was extremely low (FIFA, 2015). The situation in Turkey is almost the same. Although the dissolution of the Ottoman Empire and establishment of the Modern Turkish Republic in 1923 tries to provide logical bases for secularization and brought about gender equality in divorce, matters of inheritance, right to vote, political participation, and marriage, the ideology of inequality is still rife in many of these areas (Koca \& Hacısoftaoğlu, 2010).

\subsection{Gender Discrimination and Sports in Turkey}

Turkey holds a unique position about geography; this is all the more evident as it shares a common history with some other Islamic countries in the region. However, it clearly stands out and may never be directly compared with other Islamic countries in the area due to its attempts and approaches towards modernization evolvement and its secular system, especially concerning the development of women's liberation (Koca \& Hacisoftaoğlu, 2010). It has been argued in several studies (Koca \& Asci, 2005; Koca \& Bulgu, 2005; Koca, Asci \& Kirazci, 2005) that like many other societies in the region, patriarchy is still one of the most dominant attributes negatively affecting the perception and acceptance of female athletes in Turkey (TUIK, 2012).

These views are deeply entrenched especially when ones bear in mind that sports are perceived as masculine and seen to be synonymous with aggression and force whereas, most people perceive feminine activities as those concocted with elegance, gentleness, passivity, and weakness (Pavlidis \& Fullagar, 2016; Nogueira et al., 2017).

In addition, women who participate in sporting activities seen as masculine in nature must contend with the restrictions and marginalization, including labelling of individual sports as more appropriate for women and others as not fitting for typical female behaviour (Nogueira et al., 2017).

However, in recent years there has been a significant increase in the number of women in Turkish professional sports as well as international sports competitions, including receiving medals for international sports competitions (Koca \& Hacisoftaoğlu, 2010). The evolving roles of women, their behavioural patterns, and activities have also provided Turkish women with new opportunities and plays a significant role in female representation in professional sports in Turkey (Koca \& Hacisoftaoğlu, 2010). In 2010 alone, more women are competing were competing in volleyball $(10,599)$, taekwondo $(9,353)$, basketball $(4,714)$, karate $(4,101)$, swimming $(1,952)$, kickboxing $(1,924)$, handball $(1,859)$ and judo $(1,543)$ (Koca \& Hacısoftaoğlu, 2010).

As a result, the involvement of women in public life, in addition to their participation in sports, displays the evolution of the country. It is crucial to study the issues or, instead, the lack of gender equality in sports as somewhat missed opportunities for that sector. Several studies have shown that when equal opportunities are provided for men and women, 
İnce-Yenilmez, M. (2021), “The Impact of Media and Cultural Beliefs on Women's Participation in Sports in

Turkey: The Challenges faced by Turkish Women in Professional Sports", Sosyoekonomi, 29(48), 91-106.

it leads to immense benefits on organizational, societal and personal levels (Spaaji \& Anderson, 2012). Therefore, when gender issues are a problem, it can affect the conditions of social and economic progress, providing a shocking gap that must be filled. Gender equality benefits not only women but men as well. Equal human rights for both men and women will improve diversity in professional sports in turkey and attract the international sporting community, nevertheless. With gender equality, women will be allowed or encouraged to choose and enjoy sporting activities as long-term careers.

The purpose of the present research is to outline the specific challenges affecting the growth of Turkish female professional sports. The study is a quantitative exploration into the discriminatory issues affecting Women in sports in Turkey. The research aims to provide deeper insights into Turkey's specific gender-based problems and therefore give pathways to seek solutions for that purpose. The study will identify specific challenges that must be addressed to solve the issues of gender inequality in Turkish sports. Nevertheless, it is almost impossible to discuss gender-based problems in Turkey without looking at the role of the media. Therefore, this study will also include these themes to fully understand how the media has affected the growth of female participation in sporting activities in Turkey. With an understanding of previous research and the aim of the present study, the researcher proposes the following:

Hypothesis 1 (H1): Family influence can encourage females to take part in active sporting activities

Hypothesis 2 (H2): Wage inequality compared to their male counterparts can discourage females from taking part actively

Hypothesis 3 (H3): Misrepresentation by the media negatively affects women in sports

Hypothesis 4 (H4): Lack of facilities and equipment specially installed for female teams adversely affects women in sports

Hypothesis 5 (H5): High levels of sexual harassment negatively affects women in sports

\subsection{Gender Inequality and Women's Discrimination}

Over the years, the emergence of women into professional sports or even physical activities has met with mixed reactions across the globe. Each of these reactions has brought about diverse discriminatory issues that are deeply entrenched in the underlying gender gap. The Liberal Feminism theory advanced by Mary Wallstone, John Stuart Mill, and Harriet Taylor, as expressed in Wangari et al. (2017), equally evaluated these reactions. With focus on stereotypes, gender roles, power and oppression, sex and gender, objectification, structural and economic inequality, the Liberal Feminist theorists stated that the family, school and media (Greendorfer, 1993; Scraton, 1992; Story \& Markula, 2017) mostly affect the differences seen in female sport participation. According to the Liberal Feminists, the prejudice, division and social discrimination primarily begins from birth and may continue for life without adequate intervention. Therefore, the level of discriminatory practices hindering women from equal access to various professional sporting activities is enormous. As a direct consequence, women do not have many opportunities for competition as 
compared to their male counterparts. Liberal Feminist theorists equally hold the positions that the number of tournaments and leagues available to women at the local, national and international levels is insignificant when compared to the numerous opportunities available to their male counterparts.

Even as it is widely acknowledged that sporting activities can lead to stronger health and mental development, the level of perceptions meted to women in sports is shocking (Mine et al., 2014). Many of ideologies of the positions of women depict them as being responsible for household chores without the responsibility of bringing home financial income (Wangari et al., 2017).

Apart from these ideologies, women also experience cultural and religious limitations. For example, Brunei and Qatar did not allow women to participate professionally as Football players until the 2012 Olympics because of Islamic dress codes (Wangari et al., 2017).

In the case of Turkey, the country has been in the Olympics since 1932. However, their iconic appearance at the Olympics was made in 2012 when $50 \%$ of the participants of the Olympics were women (Leigh, 2012). Nevertheless, it is quite clear that Turkish women gained access to professional sports in the 1950s, but too much gender segregation limited the progress the country attempted making concerning gender equality. It was the standard practice at the time to hinder females from participating in "male events" and vice versa (Leigh, 2012).

Furthermore, the Liberal Feminism Theory also brings to light the underrepresentation of women in decision making positions in sports, especially in management and coaching areas. These theories were prescribed by Knnoppers, 1994 and expressed in Wangari et al. (2017). It is the perceptions that men have more capabilities for making decisions than women and are best suited for those provisions. Therefore, the Liberal Feminism Theory brings to light these discrepancies that have led to more men in critical decision-making positions in governing and administrative positions than women especially in sports organizations. These have led to lower allocations of funds and resources to women sports organizations resulting in unequal wages and awards. Nevertheless, this theory does not provide a complete view of the extent of discrimination. The theory fails to highlight the difference between women and instead depicts them as a homogenous group. Therefore, the theory fails to show their differential interests, as well as religion, family, work and educational differences, which also affects the status of women in society (Wagner, 2016).

A different theory put in place by Markula (2009), Birell and Theberge (1994) shows that the media also plays a part in the extent of discrimination. Women sports are not fully covered by the media when compared to men's sports (Moradi et al., 2011). In addition, cases where the media covers these events, these women are usually sexualized, trivialized, and marginalized; therefore, distorting their correct roles and achievements in the world of sports. 
İnce-Yenilmez, M. (2021), “The Impact of Media and Cultural Beliefs on Women's Participation in Sports in

Turkey: The Challenges faced by Turkish Women in Professional Sports", Sosyoekonomi, 29(48), 91-106.

\subsection{Sociocultural Context of Turkey}

To further understand the extent of discrimination of women in professional sports, it is also essential to look at the cultural, social, and historical contexts of Turkey especially after the dissolution of the Ottoman Empire and the establishment of the modern Turkish Republic. It is clearly acknowledged that several social reforms have been enacted to promote gender equality in political life, employment and education within the project (Acar \& Altunok, 2013: Koca \& Hacısoftaoğlu, 2011).

In the early $20^{\text {th }}$ Century, Turkey granted political, legal, and social rights to women (Muftuler-Bac, 2012). Different works of literature have documented the extent of the emancipation of Women in Turkey such as oppression within the patriarchal system (Azar \& Altunok, 2013: Toksoz, 2012). Additionally, the recent policies enacted in 2015, transformed Turkey into a conservative and traditionalist country, which states that women must be first responsible for their home as wives and mothers protecting the customs and traditions (Sumer \& Eslen-Ziya, 2015: 25). Accordingly, cultural restrictions, traditionalism and contraindications between poverty, family responsibilities, low education levels, inadequate sports and recreational facilities, state secularism, religion, and limited sports opportunities, all of which prevent women from participating in professional sports in Turkey (Koca \& Hacisoftaoğlu, 2011). A survey by Turkey Nutrition and Health Survey, 2014 equally showed that over 76.5 of women and girls do not participate in adequate physical activities or even professional sports (Ministry of Health, 2014). Accordingly, sociocultural, environmental, psychological, and individual factors that affect physical activity (O'Brien, Lloyd, \& Riot, 2017; Zhang et al., 2012) can prevent or discourage the growth of women's sports in Turkey.

\subsection{Constraints Hindering Growth in Women's Sports}

Previous research across local and international spheres has outlined lack of time, overcrowding, family problems, lack of companions and money, and long-distance to activity areas as some of the constraints hindering equality between sexes in sports activities (Stanis et al., 2010: Scott \& Mowen, 2010: Kara \& Demirci, 2010). Some reviewed works of literature have equally categorized these challenges into economic, social-cultural, and biological factors (Yan \& Thomas, 1995; FIFA, 2015; Wangari, 2017).

Some other works of literature have equally outline lack of time, lack of energy as some of the main constraints and challenges women in sports face (Story \& Markula, 2017, Wangari et al., 2017). Furthermore, another group of literature has equally stated that the level of income might be the most significant factor limiting the growth of women's sports because it plays a more substantial role in sporting activities than race, educational level, gender, and age (Shores et al., 2007; Johnson et al., 2001). 


\section{Methodology}

\subsection{Participants}

The researcher asked females (professional and amateur) athletes, over 20 years old to participate in the study. A structured questionnaire was distributed across universities, groups, and online groups were female athlete's commune. A total of 142 females, including athletes, coaches, hobbyists, and "A" level instructors, participated in the survey. The researchers obtained the demographic profile, including marital status, and any other sportrelated information.

\subsection{Instrument}

The study employed a descriptive method to analyse data collected via an 18 questions-questionnaire explicitly designed for this study. The self-administered questionnaire was developed with the help and suggestions from experts in the fields of physical education and sociology as well as from works of literature (Wilson \& Spink, 2006) to determine the particular variables that will be analysed in the study. These variables include family influence, wage inequality, sexual harassment, and unavailability of sports equipment access for women and media misrepresentation. All sub-dimensions of these factors were rated using the Likert Scale from 1 (none) to 5 (very high).

\subsection{Data Analysis}

The data collected were analysed using the IBM SPSS Statistics to make sense of the choices of participants using the descriptive methods, including the Friedman test and ChiSquare about the goals and hypothesis of the research.

\section{Results}

The descriptive statistics show that the most prominent educational level of respondents is Senior high school. According to table 1, the most prominent educational level of respondents $(26.06 \%)$ was Senior High School. $45.77 \%$ of participants were between the ages of 20 to 30 years, and $80.99 \%$ had full-time jobs. $67.68 \%$ had kids while 84 subjects $(59.15 \%)$ participated in sports clubs, and 86 participants $(60.56 \%)$ had participated in school sports teams in recent years (see Table 1 for details). 
Table: 1

Demographic Data of Participants

\begin{tabular}{|l|l|c|c|}
\hline Variables & Groups & N & $\%$ \\
\hline \multirow{4}{*}{ Education Level } & Elementary School & 22 & 15.49 \\
& Junior High School & 29 & 20.42 \\
& Senior High School & 37 & 26.06 \\
& College & 34 & 23.94 \\
\multirow{2}{*}{ Age } & Graduate School & 20 & 14.08 \\
& $20-30$ & 65 & 45.77 \\
& $31-40$ & 56 & 39.43 \\
Full-time job & $41-50$ & 17 & 11.97 \\
& $51-60$ & 4 & 2.81 \\
\hline \multirow{2}{*}{ Have kids } & $>61$ years old & 0 & 0 \\
\hline \multirow{2}{*}{ Marital Status } & Yes & 115 & 80.99 \\
\hline \multirow{2}{*}{ Participated in the sports club } & No & 27 & 19.09 \\
\hline
\end{tabular}

By analysing the collected data from the questionnaire concerning the hypothesis for this research, five variables were identified as the main challenges Turkish women encounter in sports. These variables were ordered due to their importance and effectiveness for being the issues preventing the growth of the women's sporting world in Turkey, and their preferences were determined by Friedman test as below:

1. Family influence can encourage females to take part in active sporting activities $(\chi=4.39$ of 5$)$

2. Wage Inequality, compared to their male counterparts, can discourage females from taking part actively. $(\chi=4.31$ of 5)

3. Misrepresentation by the media negatively affects women in sports $(\chi=4.16$ of 5)

4. Lack of facilities and equipment, specially installed for female teams, negatively affects women in sports. $(\chi=4.12$ of 5$)$

5. High levels of sexual harassment negatively affect women in sports $(\chi=3.89$ of 5) 
Table: 2

\section{Percentile Distribution of Participant's Choices in Completing the Questionnaire}

\begin{tabular}{|c|c|c|c|c|c|c|}
\hline A. & Family Influence & Very High & High & Med & Low & Very low \\
\hline 1. & My family feels that sports participation is a waste of time & 75 & 16 & 5 & 2 & 2 \\
\hline 2. & My family supports my sport's ambition & 64 & 23 & 6 & 4 & 2 \\
\hline 3 & My family encourages me as a result of the vitality of sports & 57 & 28 & 9 & 4 & 2 \\
\hline 4 & My family's wishes do not matter & 8 & 12 & 25 & 20 & 35 \\
\hline B. & Wage inequality & & & & & \\
\hline 5 & The pay is lower than male counterparts & 57 & 29 & 9 & 3 & 2 \\
\hline 6. & I need double jobs to create a substantial income & 40 & 28 & 25 & 4 & 3 \\
\hline 7 & The awards and sponsorships for women are very low & 48 & 39 & 9 & 4 & 0 \\
\hline $\mathrm{C}$. & Availability of Standard Sports Facility and Equipment & & & & & \\
\hline 8. & Standard facilities encourage female participation & 54 & 24 & 13 & 6 & 3 \\
\hline 9. & Equipment are available for female sports activities & 68 & 18 & 7 & 4 & 2 \\
\hline 10. & We can only use the sports facilities if the men are not using them & 65 & 19 & 10 & 4 & 2 \\
\hline 11. & Lack of proper methods for talent identification in athletics & 35 & 35 & 25 & 2 & 3 \\
\hline D. & Media misrepresentation & & & & & \\
\hline 12. & Limited exposure to mainstream media coverage & 68 & 17 & 8 & 4 & 2 \\
\hline 13. & The media fails to help attract the right sponsors & 52 & 28 & 10 & 3 & 2 \\
\hline 14 & I am objectified for my body instead of my abilities & 53 & 25 & 16 & 4 & 2 \\
\hline 15. & Objectified for my body rather than my abilities & 40 & 31 & 21 & 6 & 2 \\
\hline E. & Sexual Harassment & & & & & \\
\hline 16 & Judged for my dresses/sporting attires & 33 & 27 & 30 & 8 & 2 \\
\hline 17 & I have to make to with hostile or offensive statements from other people & 68 & 18 & 7 & 4 & 2 \\
\hline 18 & I receive requests for sexual favours and unwelcome advances & 65 & 18 & 7 & 5 & 5 \\
\hline
\end{tabular}

According to Table 2, family influence, wage inequality, availability of sports equipment and facilities, media representation, and sexual harassment are known as the most important factors influencing or rather inhibiting the growth of women's sports in Turkey.

Table: 3

\section{Results of Statistical Analysis}

\begin{tabular}{|c|c|c|c|c|c|c|}
\hline & Hypothesis & $\chi^{2}$ & $d f$ & $\mathbf{P}$ & Accept & Decline \\
\hline 1. & Family influence can encourage females to take part in active sporting activities & 16.955 & 4 & 0.002 & Yes & \\
\hline 2. & Wage inequality compared to their male counterparts can discourage females from taking part actively & 50.718 & 7 & 0.001 & Yes & \\
\hline 3. & Misrepresentation by the media negatively affects women in sports & 33.740 & 4 & 0.001 & Yes & \\
\hline 4. & Lack of facilities and equipment specially installed for female teams negatively affects women in sports & 20.294 & 5 & 0.001 & Yes & \\
\hline 5. & High levels of sexual harassment negatively affect women in sports & 51.139 & 5 & 0.001 & Yes & \\
\hline
\end{tabular}

According to Table 3, many of the hypothesis were located in the significance of 0.001 , and after analysing with the $\chi^{2}$ test, it was recognized that five factors could be the challenges that can be improved to bring about growth in women's sports in Turkey with wage inequality being the biggest challenge to the growth and development of Turkish women sports clubs. This is followed by the lack of sports equipment and facilities for women, as well as the extent of sexual harassment women must endure partaking in professional sports in Turkey.

\section{Discussion}

According to the results, the five most important variables - wage inequality, sexual harassment, media misrepresentation, lack of funding, and family influence - can significantly transform the future of Turkish women's sports. 
İnce-Yenilmez, M. (2021), “The Impact of Media and Cultural Beliefs on Women's Participation in Sports in

Turkey: The Challenges faced by Turkish Women in Professional Sports", Sosyoekonomi, 29(48), 91-106.

\subsection{Parental Influence}

The findings that family influence is significant are confirmed by previous studies by Bibi et al. (2016) on the reviews of parental problems on sports participation in Pakistan. Pelak (2005) also asserted that parental involvement could become a critical motivational factor in sports participation. Therefore, when parents fail to show their interests, it might discourage the child from following that path (Taylor et al., 2014). These parental influences are mainly in the form of attitude, motivation, and finance which are essential and influential tools for females in sports. A study by MacIntosh (2012) has equally shown that parents provide a vital support system that can aid their children in participating in sporting activities especially seeking professional paths in that regard. The present study shows that the almost lack of parental influence affects or inhibits the growth of women participation in professional sports in turkey. This is also in line with the study by Marwat et al. (2014) that sports participation among female folk in Muslim countries of the world is relatively weak. Again, Kanters et al. (2015) also state that without a clear perception of the fruitful outcomes of professional sports, parents may prevent their female wards from participating in professional sports.

\subsection{Wage Inequality}

It is depressing to say that the gap in wages earned for similar jobs between males and females is still a massive issue across countries in the world, including Turkey (Tansel et al., 2014). This glaring gap extends as far as the earnings in female sports and was observed in the findings in this study. It has also been confirmed in previous surveys and statistical evaluations stating that Male athletes on average earn double the income for females from sports with these figures going as far as ten times in some countries (Forbes, 2016: Monster Salary Index, 2017). Many of the participants stated that they made up for their insufficient income by taking on another full-time job. This glaring divide has been studied and attributed to the fact that male athletes gain more media coverage, which increases the attractions of sponsorships and endorsement deals. According to Kagnicioglu (2012), the patriarchal culture in Turkey is also responsible for the gaps witnessed in wage payments because women are perceived as weak and therefore not able to put in the kind of hard work the male athletes can boast off. Thus, the general perception is that they should be paid lesser than their male counterparts (Kagnicioglu, 2017).

\subsection{Sexual Harassment}

From the data findings, Turkish women in sports must tolerate diverse forms of sexual harassment and sometimes violence. Turkish women in sports do not only see sexual harassment, but all women are seeking paid employment across various sectors in Turkey (Westcott \& Foley Fellow, 2018). A large number of women, numbering over 409 women, were killed and 387 children abused in Turkey in 2017, mainly due to their gender (Hurriyet Daily News, 2018).Violence and sexual harassment are perhaps one of the biggest problems that must be immediately addressed for women to be able to seek any careers they prefer in Turkey. According to Bibi et al., (2016), the restrictions of societal violence exists in diverse 
aspects of women's lives. The study also indicates that fear and violence can be used as a form of social control, and limitations were present for many women who involved in outdoor recreational sports activities. Similarly, Khan et al. (2012) found that the fear of homelessness, immoral social behaviour, fear of violence were the societal problems facing diverse athletes who participated in sports activities.

\subsection{Media Misrepresentation}

From the results of this study, the media also has a significant role to play in the growth of Turkish women's sports teams. According to Lin (2012), whatever the media transmits can affect people profoundly. Therefore, depicting female athletes as sexual objects can demotivate females from partaking in professional sports. The result is equally confirmed by Trolan (3013) who studied the impact of the media on gender inequality within sports. He discovered that when the media underrepresents, trivializes, sexualizes, or heterosexualizes the image of women's body within the context of sports, the media adversely affects the development of women's professional sporting careers. According to him, this is because those images only continue to put forth an image of men's hegemonic masculinity as superiority over women and denigrate women as viewed through emotions and physical weaknesses than as athletes.

Moran (2014) also discovered that the coverage of mass media for female sports is limited and that most times, the news articles published in Turkey are for actions they took that the public considers terrible. Usually, these connate to the preferred dressings for women. According to Moran (2014), the general society in Turkey continues to hold the views that women must wear the full hijab, long dress, and full sleeves in all activities and for the sportswomen, it can be extremely hot and uncomfortable to do so which has become severe barriers. Another study confirms that female athletes are usually talked about with regard to their personal lives and physical appearance than another detail (Huffington Post, 2016).

Many other findings also show that religion, culture, and mass media may together have a significant influence on the growth of women in professional sports in Muslim countries like Turkey (Tekin, 2010: Fitzgibbons, 2015; Khalaf, 2014). The media also affects attracting the right sponsors for women's sports activities. Without comprehensive support from the economic situation in women's sports will be bleak. It is quite apparent that when the media fails to pay attention to particular sporting activities, fewer sponsors will invest in those areas (Asayesh et al., 2013).

\subsection{Unavailability of Sports Facilities and Equipment}

Respondents in the present study stated that there is a general lack of sports equipment and facilities specifically for women. The few sports equipment and facilities are grossly mismanaged and present to men first before they are available to women (Saavedra \& Martha, 2010). Huang et al. (2019) stated that providing community sports facilities have impacts that are more significant on public participation in sports. Chien (2013), who argued that the sports environment could enhance motivation to engage in sporting activities, 
primarily when factors such as aesthetics, support, safety, extensity and accessibility are all accounted for, equally asserted these. The study by Asayesh et al. (2013) equally confirms that the shortage of sports equipment and facilities can be a severe challenge influencing the growth of those sports.

\section{Conclusion}

The current study explores the different challenges faced by Turkish women in sports, including media misrepresentation, sexual harassment, parental influence, Wage inequality, and unavailability of sports equipment and facilities. The study recognizes that these constraints pose opportunities for improvement, which will otherwise lead to growth in the Turkish women's sports. The studies also reveal that despite the changes concerning women's rights implemented in the 1990s, Turkey still has a long away to go in completely changing the role and perceptions of women in the society.

A limitation of this study was the lack of resources to distribute questionnaires to diverse female athletes across Turkey adequately; the study did not collect data from a single locality and attempted to maintain randomness in a bid to avoid bias. The present study is an important finding because it denotes explicitly the constraints affecting Turkish female athletes and because no study has evaluated the restrictions discussed in this research paper at the time of investigations. The findings of the study also highlight areas that can be improved to transform the future of women's sport in Turkey significantly.

Based on the findings, the following recommendations are suggested to improve and provide a friendly environment to develop professional sports career areas for women; First, thorough policies executing the dictates of gender equality should be included in sports institutions. These include providing adequate opportunities for women coaching and avoiding sexist gender stereotypes in sports to create a positive and social educational climate for all. Secondly, elaborate physical activity and sports programs should be developed for women across local communities to increase the awareness of its importance and improve the overall perception of women in sports in Turkey. Thirdly, women with disabilities or from migrant backgrounds should be provided scholarships to build their sports careers. Campaigns should also be done to increase awareness of the positive effects of sports on the health of women and girls in the country. Finally, it should be strongly stressed that gender equality in sports will be economically beneficial for all stakeholders in sport and related industries, including the media because of higher participation, popularity of female sports, and a growing workforce.

\section{References}

Acar, F. \& G. Altunok (2013), "The 'Politics of Intimate' at the Intersection of Neoliberalism and Neo-Conservatism in Contemporary Turkey”, Women's Studies International Forum, 41, 14-23.

Ahmad, R.H. (2015), "Women sports in India-constraints, Challenges, Complications, and its Remedies", International Journal of Applied Research, 1(13), 656-659. 
İnce-Yenilmez, M. (2021), "The Impact of Media and Cultural Beliefs on Women's Participation in Sports in

Turkey: The Challenges faced by Turkish Women in Professional Sports", Sosyoekonomi, 29(48), 91-106.

Asayesh, L. \& H. Karkon \& M. Karkon \& A. Shabani (2013), “The Challenges of Athletics in Iran: A Delphi Study", European Journal of Experimental Biology, 3(6), 66-72.

Ballantyne, K.N. \& M. Kayser \& J.A. Grootegoed (2012), "Sex and Gender Issues in Competitive Sports: An Investigation of a Historical Case Leads to A New Viewpoint", British Journal of Sports Medicine, 46(8), 614-617.

Bibi, I. \& S. Khan \& W. Khan \& S.A. Abbas (2016), "Effects of Parental Problems on Sports Participation: A Study of Female Elite Athletes in Khyber Pakhtunkhwa Pakistan", Journal of Physical Education Research, 3(2), 88-95.

Bibi, I. \& S. Khan \& W. Khan (2016), "Influence of Sociocultural Problems on Sports Participation: A Case of Female Elite Athletes in Pakistan”, International Journal of Scientific \& Engineering Research, 7(6), 363-369.

Brien, O. \& K. Lloyd \& C. Riot (2017), "Exploring the Emotional Geography of the Leisure Time Physical Activity Space with Mothers of Young Children", Leisure Studies, 36(2), 220230.

Buytendijk, F.J.J. (1953), Das Fußballspiel: Eine Psychologische Studies, Würzburg:WerkbundVerlag.

Chien, Y.C. (2013), "The Application of IPA to Examine the Needs on Exercise Environment among the Middle-Aged and Elder Residents", Master's Thesis, National Pingtung University of Science and Technology, Pingtung, Taiwan.

Cleland, J. (2014), "Racism, Football Fans, and Online Message Boards: How Social Media Has Added a New Dimension to Racist Discourse in English Football”, Journal of Sport and Social Issues, 38(5), 415-431.

Feldman, D.E. \& T. Barnette \& I. Shrier \& L. Abenhaim (2003), "Is Physical Activity Differentially Associated with Different Types of Sedentary Pursuits?", Archives of Pediatrics and Adolescent Medicine, 157(8), 797-802.

FIFA (2015), FIFA, Football and Women: Why Reform Must Specify Inclusion and Investment, submitted to Mr Francias Carrard, Chair of FIFA Reform Committee, October 2015, <https://img.fifa.com/image/upload/i2berd89n7syxdj15fhq.pdf>, 23.02.2020.

Fitzgibbons, R.P. (2015), Sports and the Catholic Family, In Marital Healing, <http://www.maritalhealing.com/conflicts/sportsandfamily.php>, 23.02.2020.

Forbes (2016), The World's Highest Paid Athletes, <https://www.forbes.com/athletes/\#3cc9b30b55ae>, 23.02.2020.

Hardin, M. \& A. Croston (2012), "The Influence of Gender-Role Socialization, Media Use, and Sports Participation on Perception of Gender Appropriate Sports", Journal of Sport Behavior, 32, 207-226.

Huang, H.C. \& L.W. Liu \& C.M. Chang \& H.H. Hsieh \& H.C. Lu (2019), “The Effects of Locus of Control, Agents of Socialization and Sports Socialization Situations on the Sports Participation of Women in Taiwan", International Journal of Environmental and Public Health, (16), 18-41.

HuffingtonPost (2016), Women, Media Bias and The Olympics, $<$ https://www.huffpost.com/entry/women-media-bias-and-the_b_11459540?guccounter=1>, 23.02.2020.

Hurriyet Daily News (2018), Violence is the biggest problem women face in Turkey, $<$ http://www.hurriyetdailynews.com/violence-is-the-biggest-problem-women-face-inturkey-poll-128372>, 23.02.2020. 
İnce-Yenilmez, M. (2021), “The Impact of Media and Cultural Beliefs on Women's Participation in Sports in Turkey: The Challenges faced by Turkish Women in Professional Sports", Sosyoekonomi, 29(48), 91-106.

Kagnicioglu, D. (2017), "The role of women in working life in Turkey", WIT Transactions on Ecology and the Environment, 226, 349-358.

Kanters, M.A. \& J. Bocarro \& J. Casper (2015), "Supported or Pressured? An Examination of Agreement among Parents and Children on a Parent's Role in Youth Sports", Journal of Sport Behavior, 31(1), 64-80.

Kara, F. \& A. Demirci (2010), "An Assessment of Outdoor Recreational Behaviors and Preferences of the Residents in Istanbul", Scientific Research and Essays, 5(1), 93-104.

Khalaf, S.B.H. (2014), “Arabic Women's Participation in Sport: Barriers and Motivation among Egyptian and Kuwaiti Athletes", Doctoral Dissertation, University of Wales.

Khan, M.Y. \& A. Jamil \& U.A. Khan \& U.A. Kareem \& G. Imran (2012), "Female Students Opinion about Women's Participation in Sports", International Journal of Academic Research in Business and Social Sciences, 2(9), 275-283.

Koca, C. \& I. Hacısoftaoğlu (2010), "Sport Participation of Women and Girls in Modern Turkey", in: T. Benn \& G. Pfister \& H. Jawad (eds.), Muslim Women in Sport, United Kingdom: Routledge.

Koca, C. \& I. Hacısoftaoğlu (2011), "Struggling for Empowerment Sport Participation of Women and Girls in Turkey", in: T. Benn \& G. Pfister \& H. Jawad (eds.), Muslim Women in Sport, London: Routledge, 154-166.

LaVoi, N. \& M.J. Kane (2011), "Sociological Aspects of Sport”, in; P.M. Pederson \& J.B. Parks \& J. Quarterman \& L. Thibault (eds.), Contemporary Sport Management, Champaign, IL: Human Kinetics, 374-391.

Leigh, K. (2012), “Turkey’s Female Athletes, Like Women Nationwide, Reap Rewards”, New York Times, <https://www.nytimes.com/2012/09/09/sports/olympics/in-turkey-femaleathletes-have-come-a-long-way.html>, 23.02.2020.

Lin, T.E. \& C.C. Liu \& C.H. Lee \& F.H. Tsai \& Z.M. Chen \& S.Y. Lee (2012), "A Study of Socialization into Sport and Motivations of Athletes' Participation Sport", National Pingtung University of Education, (15), 394-406.

MacIntosh, E.W. \& L. Nicol (2012), “Athletes' Event Experiences of the XIX Commonwealth Games in Delhi, India", International Journal of Event and Festival Management, 3(1), 12-29.

Marwat, M.K. \& S. Zia-ul-Islam \& M. Waseem \& H. Khattak \& S. BiBi (2014), "Sport Performance of Muslim Women and Different Constraints in Their Way to Participation in Sport", International Journal of Humanities and Social Science, 4(10), 208-214.

Monster Salary Index (2017), "Women of India", Monster Salary Index (MSI) Report on Gender Pay Parity, <http://media.monsterindia.com/>, 23.02.2020.

Moran, R. (2014), Cultural Influences that Affect Participation in Sports Act, $<$ https://prezi.com/x7aybvzgpdve/cultural-influences-that-affect-participation-in-sportsact/>, 23.02.2020.

Müftüler-Baç, M. (2012), Gender Equality in Turkey, <http://research.sabanciuniv.edu/18894/1/20120207ATT37506EN.pdf>, 23.02.2020.

Nogueira, A. \& O. Molinero \& A. Salguero del Valle \& F. Lucidi \& S. Marquez (2017), "Identification of Gender Discrimination in Sports: Training of Agents of Change", Revista de Psicología del Deporte/Journal of Sport Psychology, 27(3), 43-49.

Pavlidis, A. \& S. Fullagar (2016), Sport, Gender, and Power, Oxford: Routledge. 
İnce-Yenilmez, M. (2021), "The Impact of Media and Cultural Beliefs on Women's Participation in Sports in

Turkey: The Challenges faced by Turkish Women in Professional Sports", Sosyoekonomi, 29(48), 91-106.

Pelak, C.F. (2005), "Negotiating Gender/race/class Constraints in the New South Africa a Case Study of Women's Soccer", International Review for the Sociology of Sport, 40(1), 53 70.

Perasso, V. (2017) Is the Gender Pay Gap in Sport Closing?, <https://www.bbc.com/news/world41685042>, 23.02.2020.

Ruseski, J.E. \& B.R. Humphreys \& K. Hallmann (2011), "Family Structure, Time Constraints, and Sport Participation”, European Review Aging and Physical Activity, 8, 57-66.

Saavedra, E. \& B. Martha (2010), "Women, Sport and Development”, International Platform on Sport and Development, (1), 23-30.

Scott, D. \& A.J. Mowen (2010), “Alleviating Park Visitation Constraints through Agency Facilitation Strategies", Journal of Leisure Research, 42(4), 535-550.

Spaaij, R. \& A. Anderson (2012), "Parents or Peers: Which Is It? Sport Socialization and Team Identification in Australia: A rejoinder to Melnick and Wann", International Review of Sociology, (47), 526-530.

Stanis, S.A.W. \& I.E. Schneider \& M.A Pereira (2010), "Parks and Health: Differences in Constraints and Negotiation Strategies for Park-based Leisure-time Physical Activity by Stage of Change", Journal of Physical Activity and Health, (7), 273-284.

Story, C. \& P. Markula (2017), "I had One Year in Junior, and Then I was too Old: Structural Age Rules and the Girlification in Canadian Elite Women's Figure Skating", Sport in Society, 20(9), 1223-1240.

Sümer, S. \& H. Eslen-Ziya (2015), "New Waves for Old Rights? Women's Mobilization and Bodily Rights in Turkey and Norway", European Journal of Women's Studies, 24(1), 23-38.

Tansel, A. \& B. Dalgıç \& A. Güven (2014), "Wage Inequality and Wage Mobility in Turkey", Discussion Paper IZA DP No.8669.

Taylor, A.C. \& J.T. Schweichler \& B.L. Jorgensen \& E.H. McKown \& M. Teresak (2014), "Parental Support Behaviors for Children Participating in Community Soccer Programs", The Sport Journal, <http://thesportjournal.org/article/parental-support-behaviors-for-childrenparticipating-in-community-soccer-programs>, 23.02.2020.

Tekin, A. (2010), "The Influence of Religious and Socio-cultural Variables on the Participation of Female University Students in Leisure Activities", World Applied Sciences Journal, 9(11), 1286-1293.

Toksöz, G. (2012), "The State of Female Labor in the Impasse of the Neoliberal Market and Patriarchal Family", in: S. Dedeoğlu \& A.Y. Elveren (eds.), Gender and Society in Turkey: The Impact of Neoliberal Policies, Political Islam and EU Accession, New York: I.B. Tauris, 47-64.

Trolan, E.J. (2013), "The Impact of the Media on Gender Inequality within the Sport", Procedia Social and Behavioral Sciences, 91, 215-227.

TÜİK (2012-b), İsgücü İstatistikleri, <http://www.tuik.gov.tr>, 23.02.2020.

Velázquez, P. (2017), "Sports Values: A European Perspective", En Proceedings ISSP 14th World Congress Sport Psychology, Sevilla (212), Madrid: Dykinson.

Wagner, M.M. (2016), “The Decline of Women's Rights in Turkey: Political Islam...or Tayyip”, Undergraduate Honors Thesis, 1069,

<https://scholar.colorado.edu/cgi/viewcontent.cgi?article=2383\&context=honr_theses >, 23.02.2020. 
Wangari, G. \& E. Kimani \& G. Wango (2017), “Challenges Faced by Women Football Players Who Participate in Football Leagues", Journal of Developing Country Studies, 2(1), 13-35.

Westcott, L. \& J.W. Foley-Fellow (2018), World Cup Harassment Highlights Issues Female Sports Journalists Face on a Daily Basis in CPJ, <https://cpj.org/blog/2018/07/world-cupharassment-highlights-issues-female-spor.php>, 23.02.2020.

Zhang, T. \& M.A. Solmon \& Z. Gao \& M. Kosma (2012), "Promoting School Students' Physical Activity: A Social Ecological Perspective", Journal of Applied Sport Psychology, 24(1), 92-105. 